Discussion Paper No. 10-053

\title{
IT is Never too Late for Changes? \\ Analysing the Relationship Between Process Innovation, IT and Older Workers
}

Irene Bertschek and Jenny Meyer

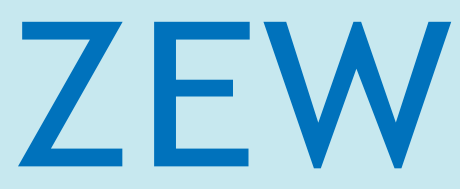

Zentrum für Europäische Wirtschaftsforschung $\mathrm{GmbH}$

Centre for European

Economic Research 
Discussion Paper No. 10-053

\title{
IT is Never too Late for Changes? Analysing the Relationship Between Process Innovation, IT and Older Workers
}

\author{
Irene Bertschek and Jenny Meyer
}

Download this ZEW Discussion Paper from our ftp server:

ftp://ftp.zew.de/pub/zew-docs/dp/dp10053.pdf

Die Discussion Papers dienen einer möglichst schnellen Verbreitung von neueren Forschungsarbeiten des ZEW. Die Beiträge liegen in alleiniger Verantwortung der Autoren und stellen nicht notwendigerweise die Meinung des ZEW dar.

Discussion Papers are intended to make results of ZEW research promptly available to other economists in order to encourage discussion and suggestions for revisions. The authors are solely responsible for the contents which do not necessarily represent the opinion of the ZEW. 


\section{Non-Technical Summary}

The key role of information technologies (IT) for productivity and growth is meanwhile undisputed. As so-called 'general purpose technologies' they enable product as well as process innovation which in turn may result in positive productivity effects and ensure firms' long-run competitiveness.

While on the one hand IT offer firms huge potentials for reshaping business processes and for supporting their innovation activities, firms are on the other hand faced to an ageing workforce. The probability and frequency of IT and software use are not the same for all age groups. In 2008, 28 percent of the individuals from 55 to 64 years used a computer at their workplace, whereas more than 50 percent of the people in each of the age groups between 25 and 54 years did so. This might be partly due to older people working in occupations without IT adoption. However, the lower level of IT use by older workers is rather caused by their IT skills, as suggested by several empirical studies, finding that older workers have lower IT skills compared to younger workers and a lower level of mastery of equipment and software.

This paper provides empirical evidence on the question whether firms' IT-enabled innovative activity is affected by the age structure of the workforce. We find that the probability of realising process innovations is positively related to the IT-intensity of the firms supporting the hypothesis of the innovation-enabling character of IT. However, the share of employees older than 49 is negatively and significantly related to firms' innovation activities. This is underpinned by a negative relationship between the interaction of this age group and the IT-intensity and process innovations. IT-specific training for older workers, by contrast, is conducive to the probability of process innovation. This result implies that not older workers in general impede firms' innovation capabilities, but older workers who lack the appropriate IT skills. 


\section{Zusammenfassung}

Die Schlüsselrolle von Informations- und Kommunikationstechnologien (IKT) für Produktivität und Wachstum ist mittlerweile unumstritten. Als Basistechnologien sind IKT in allen Branchen einsetzbar und ermöglichen Produkt- und Prozessinnovationen, welche wiederum zu positiven Produktivitätseffekten führen und die langfristige Wettbewerbsfähigkeit von Firmen sicherstellen können.

Während einerseits der Einsatz von IT Firmen die Möglichkeit bietet Geschäftsprozesse umzugestalten und sie bei ihrer Innovationsaktivität zu unterstützen, so sehen sich Firmen andererseits einer alternden Belegschaft gegenüber. Die Wahrscheinlichkeit und Häufigkeit der Nutzung von IT und Software ist indes nicht für alle Altersgruppen gleich. Im Jahr 2008 nutzten 28 Prozent der 55- bis 64-Jährigen einen Computer am Arbeitsplatz, während dies bei jeweils mehr als 50 Prozent der Beschäftigten im Alter von 25 bis 54 Jahren der Fall war. Dies mag zum Teil daran liegen, dass ältere Beschäftigte in Positionen mit keinem oder einem geringeren IT-Einsatz tätig sind. Verschiedene empirische Studien zeigen jedoch, dass ältere Beschäftigte, im Vergleich zu Jüngeren, geringere IT-Fähigkeiten und ein niedrigeres Niveau im Umgang mit IT erreichen.

Im vorliegenden Papier gehen wir der Fragestellung nach, ob die Altersstruktur der Belegschaft einen Einfluss auf die durch IT geförderten Innovationsaktivitäten hat. Die Ergebnisse zeigen, dass die Wahrscheinlichkeit Prozessinnovationen zu realisieren positiv und signifikant mit der IT-Itensität einer Firma zusammenhängt. Der Anteil der Beschäftigten, die älter als 49 Jahre sind, hängt hingegen negativ mit der Innovationswahrscheinlichkeit zusammen. Diese negative Beziehung wird dadurch verstärkt, dass die Interaktion zwischen dieser Altersgruppe und der ITIntensität negativ mit der Prozessinnovationswahrscheinlichkeit korreliert ist. ITWeiterbildung für ältere Beschäftigte ist der Innovationswahrscheinlichkeit zuträglich. Das bedeutet, dass nicht grundsätzlich ältere Beschäftigte die Innovationsfähigkeit von Firmen hemmen, sondern ältere Beschäftigte, denen die geeigneten IT-Fähigkeiten fehlen. 


\title{
IT is never too late for changes?
}

\section{Analysing the relationship between process innovation, IT and older workers}

\author{
IRENe BerTsCHEK ${ }^{*}$ \\ JENNY MEYER $\oplus$
}

August 2010

\begin{abstract}
The paper analyses the relationship between two major challenges firms are faced to: using the potentials of information technologies (IT) as an enabler of process innovations on the one hand and an ageing workforce that might interfere these potentials on the other hand. Econometric results based on firm-level data from the German manufacturing and service sectors reveal that firms with a higher IT-intensity are more likely to introduce new or improved processes. Older workers are harmful to the probability of process innovation based on IT. Leaving the negative relationship between older workers and the probability to innovate unaffected, IT-specific training for older workers is conducive to the realisation of process innovations. Thus, not older workers in general are harmful to firms' innovation capabilities, but older workers who lack the appropriate IT skills.
\end{abstract}

JEL-classification: J14, L23, O31

Keywords: process innovation, information technology, older workers

$\S$ Acknowledgement: We thank Mark McCabe and Martin Peitz as well as seminar participants at ZEW for helpful comments.

${ }^{*}$ ZEW Mannheim, ICT Research Group, P.O. Box 103443, D-68034 Mannheim, email: bertschek@zew.de.

†ZEW Mannheim, ICT Research Group, P.O. Box 103443, D-68034 Mannheim, email: meyer@zew.de. 


\section{Introduction}

The key role of information technologies (IT) for productivity and growth is meanwhile undisputed. As so-called 'general purpose technologies' (Bresnahan and Trajtenberg, 1995) they enable product as well as process innovation which in turn may result in positive productivity effects and ensure firms' long-run competitiveness as recently put forward by Brynjolfsson and Saunders (2010).

While on the one hand IT offer firms huge potentials for reshaping business processes and for supporting their innovation activities, firms are on the other hand faced to an ageing workforce. In Germany, the labour force participation rate of people between 55 and 60 has increased by 8.6 percentage points from 2000 to 2007, reaching a level of 74.6 percent. The labour force participation rate of people between 60 and 65 has even increased by 14.6 percentage points in the same period, reaching a level of 36.1 percent (Statistisches Bundesamt, 2009). The probability and frequency of IT and software use are not the same for all age groups. In 2008, 28 percent of the individuals from 55 to 64 years used a computer at their workplace, whereas more than 50 percent of the people in each of the age groups between 25 and 54 years did so. This might be partly due to older people working in occupations without IT adoption. However, the lower level of IT use by older workers is rather caused by their IT skills. Several empirical studies suggest that older workers have lower IT skills compared to younger workers and a lower level of mastery of equipment and software (e.g. de Koning and Gelderblom, 2006; Tijdens and Steijn, 2005).

These two trends - the ageing workforce on the one hand and the information technological change on the other hand - represent a big challenge for firms. The purpose of our paper is to analyse whether firms' IT-enabled innovative activity is affected by the age structure of the workforce.

We find that the probability of realising process innovations is positively related to the IT-intensity of the firms supporting the hypothesis of the innovation-enabling character of IT. However, the share of employees older than 49 is negatively and significantly related to firms' innovation activities. This is underpinned by a significant and negative interaction term between this age group and the IT-intensity. IT-specific training for older workers, by contrast, is conducive to the probability of process innovation while the negative coefficient of the share of older workers remains unchanged. This result implies that not older workers in general impede firms' innovation capabilities, but older workers who lack the appropriate IT skills. 
The paper is structured as follows: Section 2 presents the background discussion, section 3 depicts the analytical framework, section 4 describes the data. The empirical results are presented and discussed in section 5. Section 6 concludes.

\section{Background Discussion}

Information technologies are considered to be important drivers of innovation and productivity. As so-called general purpose technologies (Bresnahan and Trajtenberg, 1995) they enable firms to reshape and to optimize their business processes in order to result in productivity gains (e.g. Brynjolfsson and Hitt, 2000) 1 Despite of its importance as a prerequisite for productivity gains the link between IT and innovation is not vastly studied in the empirical literature yet $2^{2}$ Those studies investigating the relationship between innovation and IT investment at the firm level usually find a positive and significant relationship. Hempell and Zwick (2008) focus on organisational flexibility as the connecting link between IT investment and innovations where organisational flexibility comprises different dimensions of employee participation as well as outsourcing. Both strategies turn out to be positively related to IT investment. Employee participation is positively associated with product and process innovations whereas a positive relationship between outsourcing and innovation can only be observed in a short-term perspective. Licht and Moch (1999) show for the German service sector that firms, by investing in IT, attempt to improve their processes and the quality of service provision. Gera and Gu (2004) find a positive effect of IT investment per worker on product and process innovation. Ebling and Janz (1999) come to the same conclusion. They find that total investment in IT as a share of total sales are positively related to innovations. Using data for the valve manufacturing industry Bartel, Ichniowski and Shaw (2007) find that plants which adopt new IT-enhanced equipment change their business strategies and that new IT investments improve the efficiency of all stages of the production process in this specific industry.

Computer use at the workplace allows for faster information flow and more efficient work processes. Computers are the vehicles of software applications. Enterprise

\footnotetext{
${ }^{1}$ Moreover, firms with innovation experience are more likely to accompany IT usage by appropriate innovations resulting in higher productivity as shown for example by Hempell (2005).

${ }^{2}$ Most empirical studies, although pronouncing the importance of the relationship between IT and innovation, look at the link between IT and productivity, for example Brynjolfsson and Hitt (1995), Lichtenberg (1995), Greenan and Mairesse (2000), Hempell (2005).
} 
software enables to integrate all business processes with each other, making the flow of business more efficient, allowing to link suppliers and customers more closely to internal production processes and to react more quickly to changes in demand. Thus, the procedures for providing products or services might undergo considerable changes before resulting in positive productivity effects. In manufacturing firms, software applications such as computer-aided manufacturing help to optimise the production process. As product components IT lead to new or improved products e.g. in the automotive or the instruments industry where processes are integrated in products and are controlled by embedded software. While product innovation is mainly developed by firms' specific internal or external R\&D departments and involves generally a smaller fraction of employees, process innovations may rather involve a firm's whole workforce. The workforce needs to be able to adapt to new IT applications in order to ensure firms' innovative capabilities. As shown by Bartel and Lichtenberg (1987) qualified employees have comparative advantages for implementing new technologies $3^{3}$ Given the fact that the share of older employees steadily increases due to the demographic development firms have to face the question whether older workers are able to keep pace with technological progress and whether firms can ensure their innovative capabilities.

The economic literature on age-biased technological change suggests that older workers have age-related disadvantages in using new technologies compared to younger workers. The main reason is that technological change increases skill requirements and accelerates the depreciation of human capital (see for instance Bartel and Sicherman, 1993). Therefore, older workers might prefer to retire earlier instead of investing in training in particular if they are close to the legal retirement age (Bartel and Sicherman, 1993; Friedberg, 2003) [4 However, the possibilities of early retirement are much more restricted nowadays compared to the late 80 s or early 90 s not least owing to the increasing pressure on social security systems. Several studies based on individual data show that older workers are less likely to use IT since they differ significantly from younger workers with respect to occupation, education and skills (Borghans and ter Weel, 2002; Friedberg, 2003; Hirsch, MacPherson and

\footnotetext{
${ }^{3}$ See also the literature on skill-biased technological change, for instance the overview articles by Chennells and van Reenen (2002) and Card and DiNardo (2002). For an analysis of changing skill requirements owing to the diffusion of IT see Autor, Levy and Murnane (2003) and Spitz-Oener (2006).

${ }^{4}$ Apart from the motivation of older workers, firms tend to train only those workers who will gain from training (Vignoles, Galindo-Rueda and Feinstein, 2004). Therefore, firms are more likely to train younger and high skilled workers (e.g. O'Mahony and Peng, 2008).
} 
Hardy, 2000; Schleife, 2006; Weinberg, 2004). While this result holds for the nineties and for the beginning of this century, one might expect that nowadays things are different since employees older than 50 years today started using computers many years ago. Nevertheless, computer experience does not automatically lead to computer expertise, as has been found in a psychological study by Arning and Ziefle (2008). Tijdens and Steijn (2005) use individual data from 2002 and find that older workers have a lower level of mastery of IT equipment and software. Since IT applications advance continuously employees need to adapt to them on a regular basis.

From a gerontological point of view, ageing implies that older people lose important skills, showing shortcomings and deficits compared to younger ones. This affects physical skills (declining physical strength or decelerated reactions) and mental skills (cutback of brainpower, especially of fluid brainpower which is needed amongst others for finding new solutions and a fast processing of information (Börsch-Supan, Düzgün and Weiss, 2006)). Most dimensions of physical performance decline continuously beyond the age of 30 to 35 for virtually all types of measures (Stones and Kozma, 1985). Some aspects of cognitive decline already begin in healthy educated adults when they are in their 20s and 30s (Salthouse, 2009). These aspects of ageing can be related to the economic context and the labour market. A survey among personnel officers for instance shows that in general older workers show a lower learning aptitude, a lower willingness to learn or flexibility compared to younger workers (Boockmann and Zwick, 2004). These skills, however, are especially important for the implementation of new technologies or software applications. The decrease in physical and mental skills, accompanied by the process of ageing, can also be related to computer use. Psychologists find that there are significant age differences in computerized information retrieval response times (Westermann, Davies, Glendon, Stammers and Matthews, 1995) and lower computer task performance of older people (Czaja, 2001).

While there are many empirical studies on the relationship between worker age and productivity (see the surveys by Börsch-Supan et al. (2006) and Skirbekk (2004)), only few studies focus on the link between innovation and employees' age at the firm level. Rouvinen (2002) analyses the characteristics of process innovations in the Finnish manufacturing sector. He finds that an increasing average age of the employees reduces the probability of process innovation. Nishimura, Minetaki, Shirai and Kurokawa (2004) investigate the interaction between age and qualification of employees and its impact on technological progress in Japanese industries. Using 
only a small sample, they find no significant impact of older workers (above 40 years) with a high qualification (share of old workers with high education in total labour input) on the rate of technological progress in non-manufacturing industries. However, they find that the share of older workers with a high qualification reduced the rate of technological progress in the manufacturing industries in the 1990s. Schneider (2008), using linked employer-employee data from German manufacturing firms, finds significant effects of the age structure of the workforce on firms' technological innovativeness and an inverse $\mathrm{u}$-shaped link between workforce age and innovation. Innovation is an ordinal variable representing the categories no innovation, improvement or advancement of an existing product, adoption or development of a product new to the firm and adoption or development of a market novelty. The results by Verworn and Hipp (2009) show a negative effect of older workers on innovation input, measured as investments in general training, but no significant effect on three different measures of innovation output: a dummy variable for successful innovation, a dummy variable for innovation as market novelties and the turnover share due to product innovations.

Nevertheless, the relationship between age and innovation might not always be that clear ${ }^{5}$ The experience of older employees could support the implementation of a process innovation and therefore reveal a positive relationship between older workers and innovation. This experience might also, to some extent, compensate for the negative effects of cognitive decline and decreasing physical performance of ageing people. Furthermore, the IT adoption might be more productive if accompanied by the experience and knowledge of older workers on how to change processes and implement new methods and technologies within the business process.

Our study combines two important aspects discussed in different strands of the literature but not jointly analysed yet: the relationship between innovation and IT on the one hand, and the relationship between innovation and the age structure of the workforce on the other hand. Both links refer to important trends - the technological change associated with IT and the ageing workforce - implying great

\footnotetext{
${ }^{5}$ There are some studies on the individual innovativeness with a focus on great work and inventions, showing that great minds did their best work when they were older. Galenson (2005) finds that experimental innovators in arts did their greatest work in their 40s and 50s. Another study comparing conceptual innovators and experimental innovators by analysing the life cycles of nobel laureate economists, is that of Weinberg and Galenson (2005). The results show that only conceptual laureates $(75 \%)$ published their single best work in the first 10 years of their career and that experimental innovators are most productive at an average age of 61 years. Jones (2010) empirically substantiates that the age at great innovation has trended upwards by approximately 6 years over the last 100 years and is now at nearly 40 years.
} 
challenges for firms. By using firm-level data from German manufacturing and service sectors from the years 2004 and 2007, we address a time period when computers were already widely spread at the workplaces. At the same time those employees being older than 49 in 2004 were in their forties when IT started to broadly diffuse to workplaces in the beginning of the nineties. They did not grow up with these new technologies as employees who were younger than 30 in 2004.

\section{Analytical Framework}

The main purpose of our analysis is to estimate the relationship between process innovation and IT usage and to find out whether IT-enabled process innovations are affected by the age structure of the workforce. As mentioned in the previous section product innovations are rather developed by specialised research teams and thus are not tangent to the major part of the workforce. By contrast, process innovations may involve the whole workforce, and need the willingness and the ability of employees to adapt to new IT applications, new production processes or reshaped business processes. Thus, in the following, we will focus on process innovations that are supposed to be related to several factors as follows:

$$
I C_{i}=f\left(I T_{i}, L_{i}, I C_{i,-1}, I P_{i,-1}, \text { controls }\right)
$$

The innovation activity $I C_{i}$ of firm $i$ depends on the use of information technologies $I T_{i}$, on labour, $L_{i}$, and on former process $\left(I C_{i,-1}\right)$ and product $\left(I P_{i,-1}\right)$ innovation activities. ${ }^{6}$ The labour parameter $L_{i}$ reflects two types of labour heterogeneity: $L_{i}^{\text {qual }}$ represents labour heterogeneity according to qualification, $L_{i}^{a g e}$ represents the age structure of employees. Controls comprise industry and region.

In the econometric estimations the dependent variable reflects whether a firm has introduced new or significantly improved processes in the years 2004 to 2006:

$$
I C_{i}=f\left(I T_{i}, \ln L_{i}, L_{i}^{q u a l}, L_{i}^{a g e}, I C_{i,-1}, I P_{i,-1}, \text { controls }\right) .
$$

\footnotetext{
${ }^{6}$ Several empirical studies show the persistence of firms' innovative behaviour, see for instance Peters (2009) for a recent survey and empirical evidence for German firms. Innovating, in particular successful innovating, increases the probability of innovating again, commonly known as the 'success-breeds-success' hypothesis (Flaig and Stadler, 1994; Peters, 2007). There is a huge literature on the determinants of innovation, see for instance the survey by Cohen (1995) about empirical studies on innovation.
} 
As determining factors we consider labour as a measure of firm size, the qualification and the age structure of the workforce. IT intensity of the firm is measured as the share of employees working predominately at computers. We expect that due to the enabling character of IT, the IT intensity of the workforce is positively related to process innovations. The qualification structure is expected to play no or only a minor role for process innovation. On the one hand, high-qualified employees might adapt more easily to new processes than low-skilled workers. On the other hand, firms with a mainly low-skilled workforce might have the need to implement new processes in order to cut production costs. The share of older workers is expected to be negatively related to the realisation of process innovations due to their lack of adaptability and due to relatively less advanced IT skills compared to younger workers as suggested by the age-biased technological change literature. According to existing empirical results on the persistence of innovation behaviour former process and product innovations are expected to positively affect current process innovation activity.

\section{Data Description}

The firm-level data used for the empirical analysis result from the ICT survey of the Centre for European Economic Research (ZEW) and was collected in 2004 and 2007. Each year 4.400 firms were surveyed. The data are stratified according to industries (seven branches of the manufacturing industry and seven selected service sectors), to three size classes and to two regions (East/West Germany). The data are constructed as a panel, therefore the waves of 2004 and 2007 are merged in order to take into account time lags of the independent variables.7 Considering item non-response, there remains a sample of 1251 firms.

Process innovation is proxied by a dummy variable, indicating whether a firm has internally introduced new or significantly improved processes in the years 2004 to 2006 .

The age of the employees is reflected by the share of employees between 30 and 49 years and the share of workers aged 50 or older employed in the year 2003. The reference group is the share of employees aged younger than 30 years. To take

\footnotetext{
${ }^{7}$ Due to the fact that not all variables are contained in both waves, panel estimations cannot be provided.
} 
into account potential skill compensation caused by training, the share of employees older than 49 years that participated in IT-specific training measures in 2003 are included.

IT is proxied by the share of workers predominately working at a computer in the year 2004. It measures the workers' technological skills and at the same time it reflects the companies' IT intensity.

The qualification of the employees is presented by the proportion of employees being high-skilled (degree from university, university of applied sciences or university of cooperative education) and medium-skilled (master craftsman, engineer or vocational training), respectively, employed in the year 2003. The reference category is the proportion of low-skilled workers (without formal qualification).

Former product and process innovations are taken into account for two reasons: Firstly, as pointed out in section 2 innovation experience plays an important role in explaining innovative behaviour. Secondly, product and process innovations can be complements. A product innovation might require a change in the production process and vice versa. Therefore, two dummy variables representing product and process innovation in the years 2001 to 2003, respectively, are included.

A dummy variable indicates whether one or more of the chief executive officers was replaced in the years 2001 to 2003 . Such a change might stimulate innovation activities with respect to processes as well as products.

Further control variables are firm size, measured as the logarithm of the number of employees in the year 2003, firm age as logarithm, a dummy for East Germany and sector dummies controlling for sector-specific variations in innovative activity 8

Descriptive statistics of Table 1 reveal that about 66 percent of the firms introduced new or significantly improved processes in the years 2004 to 2006. On average, the share of employees in the sample being between 30 and 49 years is about 54 percent, whereas the share of employees aged 50 years or older is about 19 percent. Ten percent of these older employees have participated in IT-specific training in the year 2003. The major share of employees is medium-skilled (about 58 percent). On average, 22 percent of the employees of the firms in the sample are high-skilled. About half of the staff works predominantly at a computer. The average firm size in the sample is about 178 employees and the average firm age is around 19 years.

\footnotetext{
${ }^{8}$ The distribution of firms across sectors can be found in Table 4 in the appendix. The sector other business-related services is the reference category in the estimations.
} 
Table 1: Descriptive Statistics: Total Sample

\begin{tabular}{lcccc}
\hline \hline \multicolumn{1}{c}{ Variable } & Mean & Std. Dev. & Min. & Max. \\
\hline process innovation between 2004-2006 & 0.655 & 0.475 & 0 & 1 \\
share of empl. between 30 and 50 years & 0.536 & 0.2 & 0 & 1 \\
share of empl. above 49 years & 0.189 & 0.151 & 0 & 0.9 \\
share of empl. above 49 years w. IT-training & 0.10 & 0.240 & 0 & 1 \\
share of high-skilled empl. & 0.219 & 0.252 & 0 & 1 \\
share of medium-skilled empl. & 0.582 & 0.258 & 0 & 1 \\
share of empl. working at comp. & 0.475 & 0.34 & 0 & 1 \\
firm size (no of emp.) & 176.726 & 530.895 & 5 & 8000 \\
firm age (years) & 18.692 & 18.623 & 1 & 162 \\
change in executive board 2001-2003 & 0.244 & 0.43 & 0 & 1 \\
product innovations 2001-2003 & 0.63 & 0.483 & 0 & 1 \\
process innovations 2001-2003 & 0.739 & 0.44 & 0 & 1 \\
\hline \multicolumn{1}{c}{$\mathrm{N}$} & \multicolumn{1}{c}{1251} & \\
\hline \hline
\end{tabular}

Source: ZEW ICT survey 2004 \& 2007, own calculations.

A quarter of the firms experienced a change in the executive board in the years 2001 to 2003. Product innovations between 2001 and 2003 were made by about 63 percent of the firms and process innovations were introduced in about 74 percent in the same period.

\section{Empirical Results}

The dependent variable is a dummy variable and we assume the error term to be normally distributed. Therefore, a Probit model is used for the empirical analysis 9 To meet potential endogeneity problems, the independent variables are lagged as described in section 4. The results of the Probit estimations are shown in Table $2 \sqrt{10}$ The raw effect of the age of the workforce on the introduction of new or significantly improved processes is negative. Compared to the share of employees being younger than 30 years, an older workforce is negatively related to the probability of process innovation. This result still holds when further factors are taken into account (see specifications (2) to (4)). The finding is partly in line with former results. There

\footnotetext{
${ }^{9}$ For more details on the Probit model see Wooldridge (2002). All calculations and estimations of this paper were done with STATA 10.1.

${ }^{10}$ Since the estimated coefficients in a Probit model only allow to make a statement on the significance and the sign of an effect but not on its extent, only the marginal effects will be discussed in the following.
} 
is for example the inverse u-shaped age - innovation profile in the manufacturing sector found by Schneider (2008). The empirical evidence by Rouvinen (2002) and Nishimura et al. (2004) also supports a negative influence of older employees on the process innovation probability and technological progress in the manufacturing industries. Finally, for German service firms Meyer (2009) finds a negative relationship between the age of the workforce and the probability of technology adoption, that is one kind of possible process innovation in the service sector.

The positive relationship between the IT-intensity of a firm and the probability of process innovation (see specifications (2) to (4) of Table 2) underpins the enabling character of IT. This result is in line with the literature that analyses innovation and takes into account the impact of IT, although measured differently than here, on innovation (e.g. Ebling and Janz, 1999; Gera and Gu, 2004).

Larger firms and firms that experienced a change in the executive board are more likely to introduce process innovations. Former product and process innovations, that is innovation experience, increase the probability of introducing new or improved processes (see specifications (3) and (4)) confirming the "success breeds success" hypothesis.

In order to take account of the fact that older workers and their employers might invest in IT training in order to keep pace with technological advancement, the share of employees aged 50 years or older that participated in IT training measures in the year 2003 is included in specification (4). The variable has a positive sign and is statistically significant. Thus, IT-specific training is conducive to the probability of process innovation. However, the negative coefficient of the share of employees above 49 years still remains significant. These results suggest that not older workers in general are harmful to firms' innovation capabilities, but older workers who lack the appropriate IT skills and qualifications.

In a further step, interaction terms between both age groups and IT-intensity are taken into account. As pointed out by Ai and Norton (2003) the interpretation of marginal effects of interaction terms in nonlinear models such as Probit is not straightforward. For convenience and to simplify the interpretation of the interactions, a Linear Probability model is used for estimating the interaction effects on the probability of process innovation, the results are shown in Table $3{ }^{11}$

\footnotetext{
${ }^{11}$ The method proposed by Ai and Norton (2003) and permuted by Norton, Wang and Ai (2004) was also used to analyse the effect of the interaction between the age groups and the IT-intensity
} 
Table 2: Estimation Results: Probit

\begin{tabular}{|c|c|c|c|c|}
\hline \multicolumn{5}{|c|}{ dependent variable: dummy for process innovation } \\
\hline & $(1)$ & $(2)$ & $(3)$ & $(4)$ \\
\hline \multirow[t]{2}{*}{ share of empl. 30-49 years } & $-0.199^{* * *}$ & $-0.210^{* * *}$ & $-0.176^{* *}$ & $-0.173^{* *}$ \\
\hline & $(0.076)$ & $(0.074)$ & $(0.073)$ & $(0.072)$ \\
\hline \multirow[t]{2}{*}{ share of empl. above 49 years } & $-0.414^{* * *}$ & $-0.287^{* * *}$ & $-0.224^{* *}$ & $-0.234^{* *}$ \\
\hline & $(0.099)$ & $(0.098)$ & $(0.097)$ & $(0.097)$ \\
\hline \multirow[t]{2}{*}{ firm size (log no of emp.) } & & $0.059 * * *$ & $0.041^{* * *}$ & $0.040 * * *$ \\
\hline & & $(0.010)$ & $(0.010)$ & $(0.010)$ \\
\hline \multirow[t]{2}{*}{ firm age (log) } & & -0.020 & -0.024 & -0.024 \\
\hline & & $(0.017)$ & $(0.016)$ & $(0.016)$ \\
\hline \multirow[t]{2}{*}{ share of high-skilled empl. } & & -0.075 & -0.072 & -0.086 \\
\hline & & $(0.090)$ & $(0.088)$ & $(0.088)$ \\
\hline \multirow[t]{2}{*}{ share of medium-skilled empl. } & & 0.019 & 0.031 & 0.020 \\
\hline & & $(0.069)$ & $(0.068)$ & $(0.068)$ \\
\hline \multirow{2}{*}{$\begin{array}{l}\text { share of empl. working at } \\
\text { computers }\end{array}$} & & $0.138^{* * *}$ & $0.099^{*}$ & $0.092^{*}$ \\
\hline & & $(0.052)$ & $(0.052)$ & $(0.052)$ \\
\hline \multirow[t]{2}{*}{ change in management } & & $0.074^{* *}$ & $0.065^{* *}$ & $0.062^{* *}$ \\
\hline & & $(0.031)$ & $(0.031)$ & $(0.031)$ \\
\hline \multirow[t]{2}{*}{ process innovations 2001-2003 } & & & $0.192^{* * *}$ & $0.185^{* * *}$ \\
\hline & & & $(0.034)$ & $(0.034)$ \\
\hline \multirow[t]{2}{*}{ product innovations 2001-2003 } & & & $0.061^{* *}$ & $0.059 * *$ \\
\hline & & & $(0.030)$ & $(0.030)$ \\
\hline share of empl. above 49 & & & & $0.112^{*}$ \\
\hline with IT-training & & & & $(0.060)$ \\
\hline Sector/Regional Dummies & no & yes & yes & yes \\
\hline number of observations & 1251 & 1251 & 1251 & 1251 \\
\hline Pseudo $R^{2}$ & 0.011 & 0.074 & 0.104 & 0.106 \\
\hline
\end{tabular}

Significance levels: $\quad *: 10 \% \quad * *: 5 \% \quad * * *: 1 \%$. Average marginal effects are reported. Standard errors in parentheses. Reference categories: share of unqualified employees, share of employees aged younger than 30 years.

In specification (5) the coefficients of both age groups are insignificant. The interaction term between employees being older than 49 years and IT-intensity is negative and statistically significant. The negative coefficient of the interaction term reduces the positive coefficient of the IT-intensity and turns it even negative, depending on the share of employees being older than 49 years. This result implies that older

in the Probit model. The results did not change and are available on request. For more details on the Linear Probability model see Wooldridge (2002). The Linear Probability Model predicts 17 values outside the $[0-1]$ range of the probability of process innovation in specification (5) and 20 values in specification (6). This is less than two percent and thus a further reason to use the Linear Probability Model instead of the Probit to analyse the interactions. 
Table 3: Estimation Results: Linear Probability Model

\begin{tabular}{|c|c|c|}
\hline \multicolumn{3}{|c|}{ dependent variable: dummy for process innovation } \\
\hline & $(5)$ & (6) \\
\hline \multirow[t]{2}{*}{ share of empl. 30-49 years } & -0.090 & -0.088 \\
\hline & $(0.123)$ & $(0.123)$ \\
\hline \multirow{2}{*}{ share of empl. above 49 years } & 0.138 & 0.146 \\
\hline & $(0.162)$ & $(0.161)$ \\
\hline \multirow[t]{2}{*}{ firm size (log no of emp.) } & $0.041^{* * *}$ & $0.040^{* * *}$ \\
\hline & $(0.010)$ & $(0.010)$ \\
\hline \multirow[t]{2}{*}{ firm age (log) } & -0.022 & -0.022 \\
\hline & $(0.016)$ & $(0.016)$ \\
\hline \multirow[t]{2}{*}{ share of high-skilled empl. } & -0.072 & -0.086 \\
\hline & $(0.088)$ & $(0.089)$ \\
\hline \multirow[t]{2}{*}{ share of medium-skilled empl. } & 0.029 & 0.017 \\
\hline & $(0.070)$ & $(0.070)$ \\
\hline \multirow{4}{*}{$\begin{array}{l}\text { share of empl. working at } \\
\text { computers } \\
\text { change in management }\end{array}$} & $0.330 * *$ & $0.326^{* *}$ \\
\hline & $(0.144)$ & $(0.144)$ \\
\hline & $0.060^{*}$ & $0.056^{*}$ \\
\hline & $(0.031)$ & $(0.031)$ \\
\hline \multirow[t]{2}{*}{ process innovations 2001-2003 } & $0.199 * * *$ & $0.194^{* * *}$ \\
\hline & $(0.032)$ & $(0.032)$ \\
\hline \multirow[t]{2}{*}{ product innovations 2001-2003 } & $0.065^{* *}$ & $0.062^{* *}$ \\
\hline & $(0.030)$ & $(0.030)$ \\
\hline \multicolumn{2}{|l|}{ share of empl. above 49} & $0.104^{*}$ \\
\hline \multicolumn{2}{|l|}{ with IT-training } & $(0.056)$ \\
\hline \multirow{2}{*}{$\begin{array}{l}\text { empl. } 30-49 * \text { empl. at } \\
\text { computers }\end{array}$} & -0.159 & -0.154 \\
\hline & $(0.200)$ & $(0.200)$ \\
\hline \multirow{2}{*}{$\begin{array}{l}\text { empl. above } 49^{*} \text { empl. at } \\
\text { computers }\end{array}$} & $-0.768^{* * *}$ & $-0.800 * * *$ \\
\hline & $(0.261)$ & $(0.261)$ \\
\hline Sector/Regional Dummies & yes & yes \\
\hline \multirow{2}{*}{$\begin{array}{l}\text { number of observations } \\
\text { adjusted } R^{2}\end{array}$} & 1251 & 1251 \\
\hline & 0.117 & 0.119 \\
\hline
\end{tabular}

workers are harmful for IT-enabled process innovations. In other words, older workers are negatively related to the productive employment of IT with regard to process innovation. It seems that the experience older workers possess does not compensate for the less qualified handling of IT with regard to process innovation. Furthermore, this result could also connote that, with respect to their innovation probability, IT-intensive firms are more burdened with older workers. The interaction term be- 
tween the so called prime-age workers and IT-intensity, however, is not significant. All other variables remain significant with the same sign as in specifications (1) to (4) of the probit model.

Specification (6) additionally includes the share of older employees with IT-specific training. The corresponding coefficient is significantly positive, all other coefficients are robust and do not change qualitatively compared to specifications (1) to (4).

To sum up the results: Firms' probability to introduce new or improved processes is positively and significantly related to IT-intensity. By contrast, firms are less innovative the higher the share of older workers. Looking at interfering effects the empirical results reveal that older workers are harmful to IT-enabled process innovations, depending on the share of employees being older than 49 years. However, not older workers in general impede firms' innovative capabilities, but rather those that did not participate in IT-specific training and thus lack the appropriate skills and qualifications.

\section{Conclusions}

This paper provides empirical evidence on the relationship between IT, older workers and process innovation. IT as so-called enabling technologies (Bresnahan and Trajtenberg, 1995) allow - and necessitate - firms to reshape and to optimize their business processes in order to result in productivity gains. Older workers, on the other hand, are supposed to impede process innovation due to the depreciation of human capital. This holds in particular for IT-induced process innovations as older workers, without appropriate training, display lower IT skills than their younger counterparts.

Based on data of 1251 German firms the empirical analysis reveals that employees aged 50 years or older are negatively related to the probability of process innovations whereas firms' IT intensity is conducive to introducing new or improved processes. Looking at interfering effects between the age of employees and IT-intensity the empirical findings suggest that older workers are harmful to IT-enabled process innovation, depending on the share of older wokers. However, this does not hold for older workers in general, but rather for those that did not participate in ITspecific training and thus lack the appropriate skills and qualifications. The share 
of older workers with IT-specific training is positively and significantly related to the probability of process innovation.

Exploiting the potentials of information technology for innovativeness is an important task of firms in order to safeguard their competitiveness. The increasing age of the workforce counteracts this task as the results of the paper suggest. Therefore, firms should develop appropriate strategies and should, for instance, invest in IT-specific training for older workers to ensure that employees exhibit the skills and qualifications for efficiently working with advanced IT applications and for enhancing the innovative capabilities of firms. Policy makers could support firms in improving the IT-skills of their (older) workers. This can be done directly, for instance by sponsoring training measures, or compensating firms for the labour slack emerging during employee training or indirectly for example via tax reductions. 


\section{References}

Ai, C. and Norton, E. C. (2003). Interaction Terms in Logit and Probit Models, Economics Letters 80: 123-129.

Arning, K. and Ziefle, M. (2008). Development and Validation of a Computer Expertise Questionaire for Older Adults, Behviour and Information Technology 27(1): 89-93.

Autor, D. H., Levy, F. and Murnane, R. J. (2003). The Skill Content of Recent Technological Change: An Empirical Exploration, Quarterly Journal of Economics 118(4): 1279-1333.

Bartel, A., Ichniowski, C. and Shaw, K. (2007). How does Information Technology Affect Productivity? Plant-Level Comparisons of Product Innovation, Process Improvement and Workers Skills, The Quarterly Journal of Economics 122(4): 1721-1758.

Bartel, A. P. and Lichtenberg, F. R. (1987). The Comparative Advantage of Educated Workers in Implementing New Technology, Review of Economics and Statistics 59(1): 1-11.

Bartel, A. P. and Sicherman, N. (1993). Technological Change and Retirement Decisions of Older Workers, Journal of Labor Economics 11(1): 162-183.

Boockmann, B. and Zwick, T. (2004). Betriebliche Determinanten der Beschäftigung älterer Arbeitnehmer, Zeitschrift für ArbeitsmarktForschung 37(1): 53-63.

Borghans, L. and ter Weel, B. (2002). Do Older Workers Have More Trouble Using a Computer than Younger Workers?, Research in Labor Economics 21: 139-173.

Bresnahan, T. F. and Trajtenberg, M. (1995). General Purpose Technologies: Engines of Growth?, Journal of Econometrics 65: 83-108.

Börsch-Supan, A., Düzgün, I. and Weiss, M. (2006). Sinkende Produktivität alternder Belegschaften? Zum Stand der Forschung, in J. U. Prager and A. Schleiter (eds), Länger leben, arbeiten und sich engagieren. Chancen wertschaffender Beschäftigung bis ins Alter, Bertelsmann Stiftung, Gürtersloh, pp. 85-102.

Brynjolfsson, E. and Hitt, L. M. (1995). Information Technology as a Factor of Production: The Role of Differences Among Firms, Economics of Innovation and New Technology 3: 183-199. 
Brynjolfsson, E. and Hitt, L. M. (2000). Beyond Computation: Information Technology, Organizational Transformation and Business Performance, Journal of Economic Perspectives 14(4): 23-48.

Brynjolfsson, E. and Saunders, A. (2010). Wired for Innovation How Information Technology is Reshaping the Economy, MIT Press, Cambridge, MA.

Card, D. and DiNardo, J. E. (2002). Skill-Biased Technological Change and Rising Wage Inequality: Some Problems and Puzzles, Journal of Labor Economics 20(4): 733-783.

Chennells, L. and van Reenen, J. (2002). Technical Change and the Structure of Employment and Wages: A Survey of the Microeconometric Evidence, in N. Greenan, Y. L'Horty and J. Mairesse (eds), Productivity, Inequality and the Digital Economy, MIT Press, Cambridge, pp. 175-223.

Cohen, W. (1995). Empirical Studies of Innovative Activity, in P. Stoneman (ed.), Handbook of the Economics of Innovation and Technological Change, Blackwell Publishers, Cambridge, pp. 182-264.

Czaja, S. J. (2001). Technological Change and the Older Worker, in J. E. Birren and K. W. Schaie (eds), Handbook of the Psychology of Aging, Academic Press, USA, pp. 547-568.

de Koning, J. and Gelderblom, A. (2006). ICT and Older Workers: No Unwrinkled Relationship, International Journal of Manpower 27(5): 467-490.

Ebling, G. and Janz, N. (1999). Export and Innovation Activities in the German Service Sector: Empirical Evidence at the Firm Level. ZEW Discussion Paper No. 99-53.

Flaig, G. and Stadler, M. (1994). Success Breeds Success. The Dynamics of the Innovation Process, Empirical Economics 19(1): 55-68.

Friedberg, L. (2003). The Impact of Technological Change on Older Workers: Evidence from Data on Computer Use, Industrial and Labor Relations Review 56(3): 511-529.

Galenson, D. W. (2005). The Greatest Artists of the Twentieth Century. NBER Working Paper.

Gera, S. and Gu, W. (2004). The Effect of Organizational Innovation and Information and Communications Technology on Firm Performance, International Productivity Monitor 9: 37-51. 
Greenan, N. and Mairesse, J. (2000). Computers and Productivity in France: Some Evidence, Economics of Innovation and New Technology 9(3): 275-315.

Hempell, T. (2005). Does Experience Matter? Innovations and the Productivity of Information and Communication Technologies in German Services, Economics of Innovation and New Technology 14(4): 277-303.

Hempell, T. and Zwick, T. (2008). New Technology, Work Organisation, and Innovation, Economics of Innovation and New Technology 17(4): 331-354.

Hirsch, B. T., MacPherson, D. A. and Hardy, M. A. (2000). Occupational Age Structure and Access for Older Workers, Industrial and Labor Relations Review 53(3): 401-418.

Jones, B. F. (2010). Age and Great Invention, Review of Economics and Statistics 92(1): $1-14$.

Licht, G. and Moch, D. (1999). Innovation and Information Technology in Services, Canadian Journal of Economics 32(2): 363-383.

Lichtenberg, F. R. (1995). The Output Contributions of Computer Equipment and Personnel: A Firm-Level Analysis, Economics of Innovation and New Technology 3: 201-217.

Meyer, J. (2009). Workforce Age and Technology Adoption in Small and MediumSized Service Firms, Small Business Economics DOI 10.1007/s11187-0099246-y.

Nishimura, K. G., Minetaki, K., Shirai, M. and Kurokawa, F. (2004). Effects of Information Technology and Aging Work Force on Labor Demand and Technological Progress in Japanese Industries: 1980-1998, in P. Onofri (ed.), The Economics of an Ageing Population: Macroeconomic Issues, Kluwer Publishing, Boston.

Norton, E. C., Wang, H. and Ai, C. (2004). Computing Interaction Effects and Standard Errors in Logit and Probit Models, The Stata Journal 4(2): 103-116.

O'Mahony, M. and Peng, F. (2008). Skill Bias, Age and Organisational Change. EU KLEMS Working Paper Nr. 36.

Peters, B. (2007). Nothing's Gonna stop Innovators Now? An Empirical Investigation on the 'Success breeds Success' Hypothesis. Paper to be presented at the DRUID Summer Conference 2007. 
Peters, B. (2009). Persistence of Innovation: Stylised Facts and Panel Data Evidence, Journal of Technology Transfer 34(2): 226-243.

Rouvinen, P. (2002). Characteristics of Product and Process Innovators: Some Evidence from the Finnish Innovation Survey, Applied Economics Letters 9(9): $575-580$.

Salthouse, T. A. (2009). When Does Age-Related Cognitive Decline Begin?, Neurobiology of Aging 30: 507-514.

Schleife, K. (2006). Computer Use and the Employment Status of Older Workers, LABOUR: Review of Labour Economics and Industrial Relations 20(2): 325348.

Schneider, L. (2008). Alterung und technologisches Innovationspotential - Eine Linked-Employer-Employee-Analyse, Zeitschrift für Bevölkerungswissenschaft 33(1): $37-54$.

Skirbekk, V. (2004). Age and Individual Productivity: A Literature Survey, in G. Feichtinger (ed.), Vienna Yearbook of Population Research, Vienna.

Spitz-Oener, A. (2006). Technical Change, Job Tasks, and Rising Educational Demands: Looking outside the Wage Structure, Journal of Labor Economics 24(2): $235-270$.

Statistisches Bundesamt (ed.) (2009). Statistical Yearbook 2009 for the Federal Republic of Germany, Statistisches Bundesamt, Wiesbaden.

Stones, M. J. and Kozma, A. (1985). Physical Performance, in N. Charness (ed.), Aging and Human Performance, John Wiley \& Sons Ltd, pp. 261-291.

Tijdens, K. and Steijn, B. (2005). The Determinants of ICT Competencies among Employees, New Technology, Work and Employment 20(1): 60-73.

Verworn, B. and Hipp, C. (2009). Does the Ageing workforce Hamper the Innovativeness of Firms? (no) Evidence from Germany, International Journal of Hurman Resource Management and Development 9(2/3): 180-197.

Vignoles, A., Galindo-Rueda, F. and Feinstein, L. (2004). The Labour Market Impact of Adult Education and Training: A Cohort Analysis, Scottish Journal of Political Economy 51(2): 266-280.

Weinberg, B. A. (2004). Experience and Technology Adoption. IZA Discussion Paper No. 1051. 
Weinberg, B. A. and Galenson, D. W. (2005). Creative Careers: The Life Cycles of Nobel Laureates in Economics. NBER Working Paper 11799.

Westermann, S. J., Davies, D. R., Glendon, A. I., Stammers, R. B. and Matthews, G. (1995). Age and Cognitive Ability as Predictors of Computerized Information Retrieval, Behviour and Information Technology 14(5): 313-326.

Wooldridge, J. M. (2002). Econometric Analysis of Cross Section and Panel Data, The MIT Press, Cambridge. 


\section{A Appendix}

Table 4: Distribution of Firms Across Industries in the Samples

\begin{tabular}{lcc}
\hline \hline Industry & Observations & Percentage \\
\hline consumer goods & 108 & 8.63 \\
chemical industry & 59 & 4.72 \\
other raw materials & 87 & 6.95 \\
metal and machine construction & 148 & 11.83 \\
electrical engineering & 81 & 6.47 \\
precision instruments & 106 & 8.47 \\
automobile & 69 & 5.52 \\
wholesale trade & 55 & 4.40 \\
retail trade & 97 & 7.75 \\
transportation and postal services & 89 & 7.11 \\
banks and insurances & 58 & 4.64 \\
electronic processing and telecommunication & 108 & 8.63 \\
technical services & 103 & 8.23 \\
other business-related services & 83 & 6.63 \\
\hline sum & 1251 & 100 \\
\hline \hline
\end{tabular}

Source: ZEW ICT survey 2004 \& 2007, own calculations. 